\section{Vigor and oxidation reactions in soybean seedlings submitted to different seed chemical treatments}

\author{
Maíra Paes Lacerda ${ }^{1}$, Renan Caldas Umburanas ${ }^{1,3 *}$ id , Karla Vilaça \\ Martins $^{1}{ }^{(\mathbb{D}}$, Marco Antonio Tavares Rodrigues ${ }^{1}$ iD, Klaus Reichardt ${ }^{1,2}$ iD, \\ Durval Dourado-Neto ${ }^{1}$ iD
}

ABSTRACT: The interaction of different seed chemical treatment with seedlings germination, vigor and stress metabolism attributes needs to be better understood in soybean crop. The objectives of this study were to evaluate seed vigor, germination, and biochemical attributes of soybean seedlings as a function of different seed chemical treatments. A completely randomized experimental design was adopted, with 8 seed treatments and 4 replicates. Seed germination, vigor (first germination count, cold test, accelerated aging, emergence speed index), seedling biomass, enzimes activity and $\mathrm{SVIS}^{\circ}$ analysis were evaluated. The evaluated treatments had no difference relative to control on seed germination and vigor. Through image analysis, the seedling uniformity index were equal or higher than control with the seed chemical treatment, while vigor and growth indexes had no difference. Shoot biomass of seedlings tends to decrease with seed chemical treatments, and root biomass had no difference. Seed chemical treatments increased the activity of hydrogen peroxide in seedlings by 6 to $40 \%$ compared to control; the activity of catalase increased by 87 to $184 \%$ compared to control; and no effect was observed in lipids peroxidation. Overall, seed chemical treatment benefited the physiological activity of soybean seedlings and improved antioxidant metabolism activity. None of the seed chemical treatments used were phytotoxic.

Index terms: hydrogen peroxide content, lipid peroxidation, catalase activity.

\section{Reações de vigor e oxidação em plântulas de soja submetidas a diferentes tratamentos químicos de sementes}

RESUMO: A interação de diferentes tratamentos químicos de sementes com atributos de germinação, vigor e metabolismo de estresse em plântulas de soja precisa ser melhor compreendida. Os objetivos deste estudo foram avaliar o vigor, a germinação e atributos bioquímicos das sementes de soja em função de diferentes tratamentos químicos das sementes. Adotou-se o delineamento experimental inteiramente casualizado, com 8 tratamentos de sementes e 4 repetições. As sementes foram avaliadas quanto à germinação, vigor (primeira contagem de germinação, baixa temperatura, envelhecimento acelerado, índice de velocidade de emergência) biomassa de plântulas, atividade de enzimas e análise de SVIS ${ }^{\circledR}$. Os tratamentos avaliados não diferiram em relação ao controle na germinação e vigor das sementes. Por meio da análise de imagens, o índice de uniformidade das plântulas tende a aumentar devido ao tratamento químico das sementes, embora os índices de vigor e crescimento não tenham apresentado diferença. A biomassa da parte aérea das plântulas tende a diminuir com os tratamentos químicos das sementes, e a biomassa da raiz não apresentou diferença. Os tratamentos químicos das sementes aumentaram a atividade do peróxido de hidrogênio nas plântulas entre 6 a 40\% em relação ao controle; a atividade da catalase aumentou entre 87 a $184 \%$ em relação ao controle; e nenhum efeito foi observado na peroxidação de lipídios. De maneira geral, o tratamento químico das sementes beneficiou a atividade fisiológica das plântulas de soja e melhorou a atividade do metabolismo antioxidante. Nenhum dos tratamentos químicos de sementes usados foi fitotóxico.

Termos para indexação: conteúdo de peróxido de hidrogênio, peroxidação lipídica, atividade da catalase.
Journal of Seed Science, v.43, e202143012, 2021

http://dx.doi.org/10.1590/ 2317-1545v43247033

\author{
*Corresponding author \\ E-mail: rumbu@alumni.usp.br
}

Submitted: $12 / 28 / 2020$. Accepted: 4/9/2021.

${ }^{1}$ Escola Superior de Agricultura Luiz de Queiroz (ESALQ), Universidade de São Paulo (USP), Programa de

Pós-Graduação em Fitotecnia, 13418-900 - Piracicaba, SP, Brasil.

${ }^{2}$ Centro de Energia Nuclear na Agricultura (CENA), Universidade de São Paulo (USP), 13400-970 Piracicaba, SP, Brasil.

${ }^{3}$ Universidade Estadual do CentroOeste (Unicentro), Programa de Pós-graduação em Agronomia, 85040-167 - Guarapuava, PR, Brasil. 


\section{INTRODUCTION}

During the germination process seedlings are subject to biotic and abiotic stresses. These can reduce the vigor of the plant, delay plant development or even result in death of the seed and/or seedling in the early stages of germination. Germination and emergence failures are related to reduced plant density, and consequently, to reduced yield potential. Chemical treatment of seeds with pesticides is an effective method to reduce biotic stresses such as soil diseases, but there are still limited information of how such treatments affect seed vigor and, specially, attributes of stress metabolism. Such information could lead to a better understanding of how these compounds affect seed viability and seedling development, as well improve its use.

Seeds with high germination and vigor have greater physiological quality, which makes them more tolerant to biotic and abiotic stresses, as well as present greater growth rate index and root system development (Marcos-Filho, 2015; Finch-Savage and Bassel, 2016; Brzezinski et al., 2017). The seed physiological potential can be evaluated by germination tests, however, seeds with good physiological potential do not always present a good emergence, uniformity, and adequate plant density in the field, because stress factors, such as the presence of soil pests and pathogens, can impair this potential, especially in tropical environments.

High vigor seeds show greater uniformity in emergence in different environments (Marcos-Filho, 2015; Ebone et al., 2020). Low vigor seeds have lower initial seedling development, as well as slower vegetative growth (Schuch et al., 2009). The vigor comprises the set of attributes that gives the seed the ability to germinate, emerge and quickly result in normal seedlings under a wide range of environmental conditions. Vigor tests show resilience attributes that are not evident in germination tests (Brand et al., 2009). There are different tests to evaluate seed germination and vigor, such as germination test, speed of seedling emergence index, accelerated aging, cold test, among others. Seedling image analysis can also be correlated with soybean seed vigor (Marcos-Filho et al., 2009).

After soybean sowing, if the soil is dry or very humid, or under temperatures below $18{ }^{\circ} \mathrm{C}$, the seeds will be exposed to the harmful action of pathogens such as Aspergillus spp., Fusarium spp., Rhizoctonia solani, and Sclerotium rolfsii (França-Neto et al., 2016; Weems et al., 2015). The use of chemical treatments on seeds is a wellstablished strategy for early season soilborne pathogens management (Sartori et al., 2020) and therefore, reduce seed, seedling, and plant mortality.

The use of chemical treatment of seeds with fungicides, insecticides, and biostimulants can mitigate biotic stress factors, however it should be carefully evaluated as inadequate rates of chemical groups may cause phytotoxic effects (Sudisha et al., 2010; Carvalho et al., 2020). Some chemical groups of fungicides, such as Strobilurins, in appropriate dosage, may have biostimulant and resistance inducing effects (Sudisha et al., 2010). Small-dose of chemical groups, such as amino acids, applied in seed treatment are enough to increase antioxidant enzyme activity in soybean (Teixeira et al., 2017). It is not yet clear whether chemical groups of pesticides used in seed chemical treatment affect antioxidant related enzymes and the formation of reactive oxygen species in soybean seedlings.

There are different chemical groups of active ingredients (a.i) used in seed treatment, either as an insecticide or as a fungicide. For example, an insecticide a.i. is Fipronil, and fungicide a.i. are Pyraclostrobin (Strobilurin), Thiophanate-methyl (Benzimidazole) and Fluxapyroxade (Carboxamide), among others. Strobilurins are effective to a range of oomycetes, basidiomycete, and all groups of ascomycete fungi; benzimidazoles are effective to ascomycetes, basidiomycetes, but not oomycetes; and carboxamides had systemic activity and the spectrum was limited to seedborne Basidiomycota (Oliver and Hewitt, 2014).

For example, Strobilurins were used successfully in sunflower seed treatment increasing seed germination and seedling vigor (Sudisha et al., 2010). It is not yet clear whether Strobilurins have an antioxidant effect on tissue oxidation reactions and the formation of reactive oxygen species.

The objectives of this study were to evaluate seed germination, seedlings vigor and enzymes related to stress metabolism as a function of different seed chemical treatments. 


\section{MATERIAL AND METHODS}

The a.i. tested as seed treatment were as follow: insecticide Fipronil ((RS)-5-amino-1-(2,6-dichloro- $\alpha, \alpha, \alpha-$ trifluoro-p-tolyl)-4-trifluoromethylsulfinylpyrazole-3-carbonitrile); Strobilurin fungicide, Pyraclostrobin (Methyl N-\{2[1-(4-chlorophenyl)-1H-pyrazol-3-yloxymethyl] phenyl\}(N-methoxy)); Benzimidazole fungicide, Thiophanate-methyl (Dimethyl 4,4'-(o-phenylene)bis(3-thioallophanate)); and Carboxamide fungicide, Fluxapiroxade (3-(difluoromethyl)-1methyl-N-(3',4',5'-trifluorobiphenyl-2-yl)pyrazole-4-carboxamide).

This study was carried out in Piracicaba, São Paulo, Brazil ( $22^{\circ} 42^{\prime} \mathrm{S}$ and $47^{\circ} 37^{\prime} \mathrm{W}$, altitude $542 \mathrm{~m}$ ) with soybean seeds [Glycine max (L.) Merrill], cultivar BMX Potência RR. The provided seeds were treated using a volume of solution of $6 \mathrm{~mL} . \mathrm{kg}_{\text {[seeds] }}^{-1}$ containing the following treatments: (i) Fipronil, which consisted of $0.5 \mathrm{~g}$ [active ingredient (a.i.)].kg ${ }_{\text {[seeds] }}^{-1}$ under 0.25 g. $\mathrm{mL}^{-1}$ concentration; (ii) Fipronil + Pyraclostrobin + Thiophanate-methyl, $0.25+0.025+$ $0.225 \mathrm{~g}_{\text {[a.i.] }} . \mathrm{kg}_{\text {[seeds] }}^{-1}$, under $0.25+0.025+0.225 \mathrm{~g} \cdot \mathrm{mL}^{-1}$ concentration, respectively; (iii, iv, v, and vi) Fluxapyroxade, $0.15,0.25,0.5$ and $0.75 \mathrm{~g}_{\text {[a.j.] }} \cdot \mathrm{kg}_{\text {[seeds] }}^{-1}$, under $0.333 \mathrm{~g} . \mathrm{mL}^{-1}$ concentration; (vii) Pyraclostrobin, $0.1 \mathrm{~g}_{\text {[a.i.] }} \cdot \mathrm{kg}_{\text {[seeds] }}{ }^{-1}$, under $0.5 \mathrm{~g} . \mathrm{mL}^{-1}$ concentration; and control (seeds containing only water in the volume of solution). A completely randomized experimental design was adopted, with eigth seed treatments and four replicates. Seeds were used in the tests within 72 hours after treatment.

Seed water content was determined at the same time as other evaluations were made, with two replicates per experimental unit. Samples were placed in an oven at $105 \pm 3{ }^{\circ} \mathrm{C}$ for $24 \mathrm{~h}$, as recommended by Brasil (2009). The results were expressed on a wet basis. Germination and vigor tests were performed with four replicates of 50 seeds.

Germination was conducted on a paper towel (Germitest ${ }^{\circledR}$ ), previously moistened with a weight of water 2.5 times the weight of the dry paper using distilled water, and then kept in a germinator at a constant temperature of $25^{\circ} \mathrm{C}$. The first count of germination was carried out on the fifth day, and the last count three days later, using as a standard of normal seedlings the pattern suggested by Brasil (2009).

Cold test consisted of a procedure similar to that described in the germination test on paper adopting $10^{\circ} \mathrm{C}$ in a cold chamber and kept for seven days. Then the samples were placed in a germinator at $25^{\circ} \mathrm{C}$ for five days (Barros, 1999). The evaluation of normal seedlings was carried out, according to germination test criteria. The results were expressed as percentage of normal seedlings.

Accelerated aging was performed in a plastic germination box $(110 \times 110 \times 30 \mathrm{~mm})$ containing $40 \mathrm{~mL}$ of water, in which 200 seeds were distributed for each treatment in a single layer, that covered the entire surface of a metal screen above the water level. Thereafter, the germination box was covered and placed in a Biochemical Oxygen Demand (BOD) aging chamber at $41^{\circ} \mathrm{C}$, for $48 \mathrm{~h}$ (Marcos-Filho, 2015). After that, the seeds proceeded to the germination test as described previously and data were presented in percentage.

For the seedling emergence seeds were arranged in a 7-cm layer of medium-textured sand, placed inside plastic boxes $(470 \times 300 \times 110 \mathrm{~mm})$. After sowing, they were covered with $3 \mathrm{~cm}$ of sand moistened with $60 \%$ of the water retention capacity of the substrate. The boxes were kept in a greenhouse. Daily evaluations were carried out, by registering the number of emerged seedlings in each experimental unit until the fifteenth day after sowing, when the mean of emerged seedlings was determined. To calculate the Speed of seedling emergence index (ESI), the equation proposed by Maguire (1962) was used.

Seedling dry biomass was determined by the same procedure as the germination and first germination count test, but with 10 seeds per replicate. The seeds were arranged equidistantly and longitudinally in the upper third of the paper, with the root end facing to the bottom of the paper (Nakagawa, 1999). Four days after installation, the germinated and normal seedlings were removed from the growth chamber, separated between shoot and root, and kept in an oven at $60{ }^{\circ} \mathrm{C}$ until reaching constant weight.

Image analysis used the same procedure as in the germination taking images with 25 seeds per replicate and keeping for three days in the germination chamber. Then the seedlings and non-germinated seeds were arranged 
equidistantly on a black paper sheet. At that time images were taken and scanned at 100 dpi resolution on an HP Scanjet $2410^{\circledR}$ device scanner and processed in the Photosmart ${ }^{\circledR}$ software. The scanner was placed inside an aluminum box $(600 \times 500 \times 120 \mathrm{~mm})$ in an inverted position. The images produced were analyzed by the Seed Vigor Imaging System $\left(\mathrm{SVIS}^{\circledR}\right)$ software, obtaining the mean vigor, growth, and uniformity index for each experimental unit. The vigor index value is the result of a combination of growth and uniformity indexes, values ranging from 0 to 1000 (Hoffmaster et al., 2003; Carvalho et al., 2020).

For biochemical determinations, 10 seeds were sown per replicate by the same method as seedling emergence in sand test, and the leaves were harvested seven days after installation (VE growth stage, Fehr and Caviness, 1977). Fresh leaf biomass was analyzed for hydrogen peroxide content $\left(\mathrm{H}_{2} \mathrm{O}_{2}\right)$ (Alexieva et al., 2001), catalase activity (CAT) (Kraus et al., 1995; Azevedo et al., 1998), and lipid peroxidation (LP) content (Heath and Packer, 1968).

\section{Statistical analysis}

The Shapiro-Wilk statistic test indicated normality for all data. Data were submitted to analysis of variance (ANOVA) and when attested significant difference ( $\operatorname{Pr}>F: \leq 0.05)$, mean values were compared by the Duncan test $(p \leq 0.05)$.

\section{RESULTS AND DISCUSSION}

\section{Germination and vigor tests}

Germination test on paper four days after sowing (DAS) showed that germination with Fipronil was greater than that of Pyraclostrobin, while the other treatments did not differ among themselves. At 7 DAS, germination did not differ among all treatments and was overall above $95 \%$ (Table 1). Pyraclostrobin alone, despite presenting worse performance at 4 DAS, was equal to the other treatments at 7 DAS.

Cold test showed that the germination of seeds ranged from 87 to $95 \%$ and was higher for the Fipronil treatment compared to Fipronil + Pyraclostrobin + Thiophanate-methyl treatment, while the other treatments did not differ among themselves (Table 1). Cold test use as base temperature $10^{\circ} \mathrm{C}$, which is close to the lower basal temperature of soybean considered close to $4{ }^{\circ} \mathrm{C}$ (Lamichhane et al., 2020). The temperature used in cold test is enough to causes stress which

Table 1. Water content (WC), germination four and seven days after emergence $\left(G_{4}\right.$ and $G_{7}$, respectively), cold test $(\mathrm{Ct})$, accelerated aging $(\mathrm{Aa})$, and emergence speed index (ESI) of the evaluated soybean seed treatments.

\begin{tabular}{ccccccc}
\hline $\begin{array}{c}\text { Treatment } \\
\left(\mathrm{g}_{\text {[active ingredient] }} \mathrm{kg}_{[\text {[seeds] }}{ }^{-1}\right)\end{array}$ & $\mathrm{WC}^{1}$ & $\mathrm{G}_{4}{ }^{1}$ & $\mathrm{G}_{7}{ }^{1}$ & $\mathrm{Ct}^{1}$ & $\mathrm{Aa}^{1}$ & $\mathrm{ESI}^{2}$ \\
\hline $\begin{array}{c}\text { Control } \\
\text { Fipronil (0.5) }\end{array}$ & 10.8 & $90 \mathrm{ab} *$ & $96 \mathrm{a}$ & $89 \mathrm{ab}$ & $92 \mathrm{a}$ & $14.7 \mathrm{a}$ \\
$\begin{array}{c}\text { Fipronil + Pyraclostrobin }+ \\
\text { Thiophanate-methyl (0.25 }\end{array}$ & 10.7 & $97 \mathrm{a}$ & $99 \mathrm{a}$ & $95 \mathrm{a}$ & $92 \mathrm{a}$ & $14.1 \mathrm{a}$ \\
$\begin{array}{c}\text { 0.025 + 0.225, respectively) } \\
\text { Fluxapiroxade (0.15) }\end{array}$ & 10.5 & $90 \mathrm{ab}$ & $98 \mathrm{a}$ & $87 \mathrm{~b}$ & $93 \mathrm{a}$ & $14.3 \mathrm{a}$ \\
Fluxapiroxade (0.25) & 10.6 & $91 \mathrm{ab}$ & $95 \mathrm{a}$ & $93 \mathrm{ab}$ & $89 \mathrm{a}$ & $14.4 \mathrm{a}$ \\
Fluxapiroxade (0.5) & 10.1 & $94 \mathrm{ab}$ & $95 \mathrm{a}$ & $92 \mathrm{ab}$ & $91 \mathrm{a}$ & $15.0 \mathrm{a}$ \\
Fluxapiroxade (0.75) & 10.6 & $95 \mathrm{ab}$ & $98 \mathrm{a}$ & $93 \mathrm{ab}$ & $92 \mathrm{a}$ & $14.7 \mathrm{a}$ \\
Pyraclostrobin (0.1) & 11.1 & $91 \mathrm{ab}$ & $96 \mathrm{a}$ & $90 \mathrm{ab}$ & $87 \mathrm{a}$ & $16.1 \mathrm{a}$ \\
\hline Significance & 11.1 & $90 \mathrm{~b}$ & $95 \mathrm{a}$ & $90 \mathrm{ab}$ & $90 \mathrm{a}$ & $15.3 \mathrm{a}$ \\
CV (\%) & $\mathrm{ns}$ & $*$ & $*$ & $*$ & $*$ & $*$ \\
\hline
\end{tabular}

${ }^{1}$ Mean values in percentage; ${ }^{2}$ Seedlings emerged per day; ${ }^{3}$ Means followed by the same letter, in the column, do not differ, according to the Duncan test $(p \leq 0.05)$; ${ }^{*}$ Significant at $p \leq 0.05$; ns: non-significant. 
reflects in seed vigor, and this test is made just to see which seeds will behave under temperature stress conditions.

Accelerated aging ranged from 87 to $92 \%$ and did not differ among treatments (Table 1). The cold and accelerated aging tests evidence seed vigor, but each one analyzes different aspects of seed vigor (Marcos-Filho et al., 2009). These tests are complementary because they simulate contrasting environmental conditions, cold test give results about temperature stress and accelerated aging will give results about storage deterioration.

The emergence speed index (ESI) did not present difference among treatments (Table 1), which evidences that the seed chemical treatments used keep the seed physiological quality similar to control, as the vigor of the soybean seed has a direct relationship to the ESI (Ebone et al., 2020). The ESI and uniformity are important attributes in the concept of seed vigor, being the first germination count a fast and relevant test (Marcos-Filho, 2015).

For the seedling biomass test, seedling shoot dry biomass was higher in the control treatment compared to Fipronil

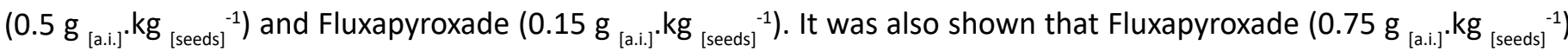
was higher than Fluxapyroxade $\left(0.15 \mathrm{~g}_{\text {[a.i] }} \cdot \mathrm{kg}_{\text {[seeds] }}{ }^{-1}\right)$, while the other treatments had no difference among themselves. Seedling root dry biomass did not differ among treatments (Table 2). The relationship between the root to shoot ratio was higher for the Fipronil $\left(0.5 \mathrm{~g}_{\text {[a.i.] }} \cdot \mathrm{kg}_{\text {[seeds] }}{ }^{-1}\right)$ and Fluxapyroxade treatments $\left(0.15\right.$ and $\left.0.25 \mathrm{~g}_{\text {[a.i.] }} \cdot \mathrm{kg}_{\text {[seeds] }}{ }^{-1}\right)$ compared to the control. The other treatments did not differ among themselves (Table 2).

Both seed chemical treatments with Fipronil at $0.5 \mathrm{~g}_{[\text {[a.j. }} \cdot \mathrm{kg}_{[\text {[seeds] }}^{-1}$ and Fluxapyroxade at $0.15 \mathrm{~g}_{[\text {a.i.] }} \mathrm{kg}_{[\text {[seeds] }}{ }^{-1}$ reduced shoot biomass in seedlings in $16 \%$ compared to control. The fungicide absorbed by seedlings is reported to be less than half of what is present in the seed, and most of it concentrated in the cotyledons (Sartori et al., 2020), which partly explain the more pronounced effect in the aboveground part of the seedling.

The root biomass had no difference among treatments, however, the relationship between root and shoot increased with Fipronil at $0.5 \mathrm{~g}_{\text {[a.i.] }} . \mathrm{kg}_{\text {[seeds] }}{ }^{-1}$, and Fluxapiroxade at 0.15 and $0.25 \mathrm{~g}_{\text {[a.i.] }} \cdot \mathrm{kg}_{\text {[seeds] }}{ }^{-1}$. Changes in the relationship between root and shoot biomass were also reported when soybean seedlings were under stress conditions, such as water restriction (Umburanas et al., 2019), which evidences the plasticity in the soybean seedling development in response to external factors.

Image analysis showed that the vigor and growth index at 3 DAS did not differ between treatments (Table 2). The uniformity index was higher for the Fipronil, Fipronil + Pyraclostrobin + Thiophanate-methyl and Fluxapyroxade

Table 2. Shoot biomass ( $\mathrm{Sb})$, root biomass $(\mathrm{Rb})$, root by shoot ratio (Rb/Sb), vigor index (Vi), growth index (Gi), and uniformity index $(\mathrm{Ui})$ of the evaluated soybean seed treatments.

\begin{tabular}{ccccccc}
\hline $\begin{array}{c}\text { Treatment } \\
\left(\mathrm{g}_{\text {[active ingredient] }} \mathrm{kg}_{\text {[seeds] }}^{-1} \text { ) }\right.\end{array}$ & $\mathrm{Sb}^{1}$ & $\mathrm{Rb}$ & $\mathrm{Rb} / \mathrm{Sb}$ & $\mathrm{Vi}^{2}$ & $\mathrm{Gi}^{2}$ & $\mathrm{Ui}^{2}$ \\
\hline $\begin{array}{c}\text { Control } \\
\text { Fipronil (0.5) }\end{array}$ & $190 \mathrm{a}^{3}$ & $69 \mathrm{a}$ & $0.36 \mathrm{~b}$ & $859 \mathrm{a}$ & $863 \mathrm{a}$ & $851 \mathrm{~b}$ \\
$\begin{array}{c}\text { Fipronil + Pyraclostrobin }+ \\
\text { Thiophanate-methyl (0.25 }+\end{array}$ & $160 \mathrm{bc}$ & $72 \mathrm{a}$ & $0.44 \mathrm{a}$ & $928 \mathrm{a}$ & $945 \mathrm{a}$ & $892 \mathrm{a}$ \\
$0.025+0.225$, respectively) & $170 \mathrm{abc}$ & $69 \mathrm{a}$ & $0.40 \mathrm{ab}$ & $929 \mathrm{a}$ & $946 \mathrm{a}$ & $892 \mathrm{a}$ \\
Fluxapiroxade (0.15) & $160 \mathrm{c}$ & $71 \mathrm{a}$ & $0.44 \mathrm{a}$ & $936 \mathrm{a}$ & $952 \mathrm{a}$ & $900 \mathrm{a}$ \\
Fluxapiroxade (0.25) & $170 \mathrm{abc}$ & $74 \mathrm{a}$ & $0.44 \mathrm{a}$ & $884 \mathrm{a}$ & $880 \mathrm{a}$ & $894 \mathrm{a}$ \\
Fluxapiroxade (0.5) & $180 \mathrm{abc}$ & $70 \mathrm{a}$ & $0.40 \mathrm{ab}$ & $892 \mathrm{a}$ & $892 \mathrm{a}$ & $893 \mathrm{a}$ \\
Fluxapiroxade (0.75) & $190 \mathrm{ab}$ & $76 \mathrm{a}$ & $0.41 \mathrm{ab}$ & $885 \mathrm{a}$ & $888 \mathrm{a}$ & $881 \mathrm{ab}$ \\
Pyraclostrobin (0.1) & $180 \mathrm{abc}$ & $72 \mathrm{a}$ & $0.40 \mathrm{ab}$ & $894 \mathrm{a}$ & $905 \mathrm{a}$ & $871 \mathrm{ab}$ \\
\hline Significance & $*$ & $*$ & $*$ & $*$ & $*$ & $*$ \\
CV (\%) & 8 & 16 & 12 & 5 & 7 & 3 \\
\hline
\end{tabular}

${ }^{1}$ Miligrams; ${ }^{2}$ Dimensionless; ${ }^{3}$ Means followed by the same letter, in the column, did not differ according to the Duncan test ( $\left.p \leq 0.05\right) ;{ }^{*}$ Significant at $\mathrm{p} \leq 0.05$. 
treatments $\left(0.15,0.25\right.$ and $\left.0.50 \mathrm{~g}_{\text {[a.i.] }} \mathrm{kg}_{[\text {[seds] }}{ }^{-1}\right)$ compared to the control, while the other treatments did not differ among themselves (Table 2). The vigor index and growth index also evidenced that the seedlings of the chemical treatments did not differ from the control. Although, the uniformity index tends to be higher in seedlings from chemical treatments relative to control, especially for Fipronil $\left(0.5 \mathrm{~g}_{\text {[a.j. }} \cdot \mathrm{kg}_{[\text {[seeds] }}^{-1}\right)$ Fipronil + Pyraclostrobin + Thiophanate-methyl $\left(0.25+0.025+0.225 \mathrm{~g}_{[\text {[a.j.] }} \cdot \mathrm{kg}_{[\text {[seds] }}{ }^{-1}\right)$ Fluxapyroxade $\left(0.15 ; 0.25 ;\right.$ and $\left.0.5 \mathrm{~g}_{\text {[a.i.]. }} \mathrm{kg}_{\text {[seeds] }}{ }^{-1}\right)$.

In none of the seed germination and vigor tests the chemical treatments performed worse than the control, which indicates that the tested seed chemical treatments did not impair seed vigor within the dosages of this study.

The germination test on paper, cold test, and accelerated aging presented values that ranged from 95-99\%, 87$95 \%$, and $87-93 \%$, respectively. All these tests attest great viability of the seeds and evidence that the tested chemical treatments did not damage the physiological quality. The seeds of this study had high vigor as verified in the tests carried out, and it is implied that the tested chemical treatments did not affect this attribute, when the seeds treatments were applied $72 \mathrm{~h}$ before the evaluations.

\section{Biochemical attributes of seedlings}

Hydrogen peroxide $\left(\mathrm{H}_{2} \mathrm{O}_{2}\right)$ content was higher in seeds treated with Fipronil and Pyraclostrobin compared to Fluxapyroxade $\left(0.15 \mathrm{~g}_{\text {[a.i.] }} \mathrm{kg}_{\text {[seeds] }}{ }^{-1}\right)$ and control, while they did not differ from other treatments. The $\mathrm{H}_{2} \mathrm{O}_{2}$ content was also higher for the Fluxapyroxade treatment $\left(0.25\right.$ and $\left.0.75 \mathrm{~g}_{\text {[a.i.] }} . \mathrm{kg}_{[\text {[seeds] }}^{-1}\right)$ than for the control, while they did not differ from the other treatments (Table 3). The activity of $\mathrm{H}_{2} \mathrm{O}_{2}$ in seedlings increased, relative to control, in $40 \%$ with Fipronil at $0.5 \mathrm{~g}_{\text {[a.i.] }} \mathrm{kg}_{\text {[seeds] }}{ }^{-1}$; in $26 \%$ with Fluxapyroxade at $0.25 \mathrm{~g}_{\text {[a.i.] }} \mathrm{kg}_{\text {[seeds] }}{ }^{-1} ;$ in $29 \%$ with Fluxapyroxade at $0.75 \mathrm{~g}_{\text {[a.i.] }} \cdot \mathrm{kg}_{\text {[seeds] }}{ }^{-1}$; and in $34 \%$ with Pyraclostrobin at $0.1 \mathrm{~g}_{\text {[a.i.] }} . \mathrm{kg}_{\text {[seeds] }}{ }^{-1}$.

The $\mathrm{H}_{2} \mathrm{O}_{2}$ is a free radical that is transformed into $\mathrm{H}_{2} \mathrm{O}$ by antioxidant enzymes such as peroxidase and catalase. $\mathrm{H}_{2} \mathrm{O}_{2}$ content is related to the activity of antioxidant enzymes, especially superoxide dismutase, which catalyze the transformation of the $\mathrm{O}_{2}{ }^{*}$ - radical. Higher $\mathrm{H}_{2} \mathrm{O}_{2}$ content may be related to lower activity of the glyoxylate metabolic pathway, which is responsible for reducing the $\mathrm{H}_{2} \mathrm{O}_{2}$ activity (Alhasawi et al., 2015).

The increase content of $\mathrm{H}_{2} \mathrm{O}_{2}$ in soybean was reported to induce tolerance probably by a stress memory (Andrade et al., 2018). Possibly the higher $\mathrm{H}_{2} \mathrm{O}_{2}$ content of seedlings derived from the Pyraclostrobin seed treatment evidence that inductive stress was more pronounced in these plants, but more studies should be performed in further stages of soybean development to test this hypothesis.

Catalase activity (CAT) at 11 DAS was higher than the control in the Fipronil + Pyraclostrobin + Methyl Thiophanate, Fluxapyroxade ( 0.15 and $0.50 \mathrm{~g}_{\text {[a.i.] }} . \mathrm{kg}_{\text {[seeds] }}^{-1}$ ) and Pyraclostrobin treatments. All other treatments did not differ among themselves (Table 3). The activity of catalase in seedlings increased, relative to control, in $181 \%$ with Fipronil + Pyraclostrobin + Thiophanate-methyl at $0.25+0.025+0.225 \mathrm{~g}_{[\text {[a.j.] }} . \mathrm{kg}_{[\text {[seeds] }}^{-1}$, respectively; in $184 \%$ with Fluxapyroxade at $0.15 \mathrm{~g}{ }_{[\text {[a.i.] }} . \mathrm{kg}$ ${ }_{\text {[seeds] }}^{-1}$; in $156 \%$ with Fluxapyroxade at $0.50 \mathrm{~g}_{\text {[a.i.] }} . \mathrm{kg}_{\text {[seeds] }}{ }^{-1}$; and in $138 \%$ with Pyraclostrobin at $0.1 \mathrm{~g}_{\text {[a.i.] }} \mathrm{kg}_{\text {[seeds] }}{ }^{-1}$.

Catalase (CAT) is involved in the degradation of $\mathrm{H}_{2} \mathrm{O}_{2}$ in water and oxygen, being an effective antioxidant agent in plants (Tehrani and Moosavi-Movahedi, 2018). Increased CAT activity is described as a coordinated mechanism of cellular detoxification with changes in the activities of peroxidase and superoxide dismutase enzymes in physic nut (Jatropha curcas L.) (Gao et al., 2008). The increase in CAT activity provided by seed chemical treatments evidence that these treatments provided a resistance inducing effect in soybean seedlings.

It was already reported in other studies that CAT acts together with peroxidase to reduce the risk of formation of $\mathrm{OH}^{-}$(hydroxyl) radicals, a highly reactive radical (Tehrani and Moosavi-Movahedi, 2018). Maintenance of CAT and peroxidase activity at high levels contribute to reach the balance between formation and removal of free radicals from the intracellular environment (Tehrani and Moosavi-Movahedi, 2018). However, the activity of this enzyme varies between species, as well as the duration of stress the plant is undergoing (Chaparzadeh et al., 2004).

Lipid peroxidation (Lp) did not differ among treatments. (Table 3). The Lp test showed that seed chemical treatments did not modify this stress indicator. These results corroborate to the seedling germination and vigor analyzes, in which 
Table 3. Hydrogen peroxide content $\left(\mathrm{H}_{2} \mathrm{O}_{2}\right)$, catalase activity (CAT), and lipid peroxidation (LP) content of the evaluated soybean seed treatments.

\begin{tabular}{cccc}
\hline Treatment $\left(\mathrm{g}_{\text {[active ingredient] }} \cdot \mathrm{kg}_{[\text {[seeds] }}{ }^{-1}\right)$ & $\mathrm{H}_{2} \mathrm{O}_{2}{ }^{1}$ & $\mathrm{CAT}^{2}$ & $\mathrm{LP}^{3}$ \\
Control & $827 \mathrm{c}^{4}$ & $32 \mathrm{~b}$ & $31 \mathrm{a}$ \\
Fipronil (0.5) & $1,158 \mathrm{a}$ & $65 \mathrm{ab}$ & $33 \mathrm{a}$ \\
$\begin{array}{c}\text { Fipronil + Pyraclostrobin + Thiophanate-methyl } \\
(0.25+0.025+0.225, \text { respectively) }\end{array}$ & $964 \mathrm{abc}$ & $90 \mathrm{a}$ & $33 \mathrm{a}$ \\
Fluxapiroxade (0.15) & $876 \mathrm{bc}$ & $91 \mathrm{a}$ & $32 \mathrm{a}$ \\
Fluxapiroxade (0.25) & $1,039 \mathrm{ab}$ & $68 \mathrm{ab}$ & $36 \mathrm{a}$ \\
Fluxapiroxade (0.5) & $953 \mathrm{abc}$ & $82 \mathrm{a}$ & $31 \mathrm{a}$ \\
Fluxapiroxade (0.75) & $1,063 \mathrm{ab}$ & $60 \mathrm{ab}$ & $38 \mathrm{a}$ \\
Pyraclostrobin (0.1) & $1,104 \mathrm{a}$ & $76 \mathrm{a}$ & $*$ \\
\hline Significance & $*$ & $*$ & 16 \\
CV (\%) & 13 & 32 & 16 \\
\hline
\end{tabular}

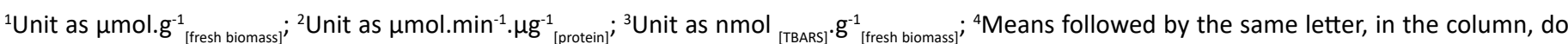
not differ, according to the Duncan test $(p \leq 0.05) ;{ }^{*}$ Significant at $p \leq 0.05$.

the seed chemical treatments remained at adequate levels. Despite the increase in $\mathrm{H}_{2} \mathrm{O}_{2}$ in Fipronil and Pyraclostrobin treatments, the magnitude was not high enough to significantly change the levels of LP.

In relation to the control, seed chemical treatments increased the activity of $\mathrm{H}_{2} \mathrm{O}_{2}$ from 6 to $40 \%$, and the activity of CAT from 87 to $184 \%$, while no effect was observed in Lp. Even with this increase in CAT and $\mathrm{H}_{2} \mathrm{O}_{2}$, that didn't affected germination in all treatments, which makes the soybean able to handle the possible stress that the chemical treatment could cause.

\section{CONCLUSIONS}

The evaluated seed chemical treatments have no difference relative to control on seed germination and vigor by the germination test on paper, cold test, accelerated aging, and emergence speed index. Through image analysis, the seedling uniformity index are equal or higher than control with the seed chemical treatment, although vigor and growth indexes have no difference among treatments. Shoot biomass of seedlings decreases compared to control only with Fipronil at $0.5 \mathrm{~g}_{\text {[a.j.] }} . \mathrm{kg}_{\text {[seeds] }}^{-1}$ or with Fluxapyroxade at $0.15 \mathrm{~g}_{\text {[a.i.] }} \mathrm{kg}_{\text {[seeds] }}{ }^{-1}$. Seedling root biomass have no difference among seed treatments. The activity of hydrogen peroxide and catalase in seed with the evaluated chemical treatments are equal or higher than control. The lipids peroxidation activity has no difference among seed chemical treatments. Overall, seed chemical treatment benefits the physiological activity of soybean seedlings and improves antioxidant metabolism activity. None of the used pesticides were phytotoxic in the conditions of this study.

\section{ACKNOWLEDGMENTS}

We acknowledge the Universidade de São Paulo, Escola Superior de Agricultura "Luiz de Queiroz" for the structure made available to carry out this research, especially the staff of the Departamento de Produção Vegetal (LPV) and the Laboratório Multiusuário em Produção Vegetal.

We also acknowledge funding from Coordenação de Aperfeiçoamento de Pessoal de Nível Superior (CAPES), from Fundação de Amparo à Pesquisa do Estado de São Paulo (FAPESP, Grant n.2016/06310 0 and 2017/24059 5) and from Conselho Nacional de Desenvolvimento Cientifco e Tecnológico (CNPq, Grant n.140209/2015 8). 


\section{REFERENCES}

ALEXIEVA, V.; SERGIEV, I.; MAPELLI, S.; KARANOV, E. The effect of drought and ultraviolet radiation on growth and stress markers in pea and wheat. Plant, Cell Environment, v.24, n.12, p.1337-1344, 2001. https://doi.org/10.1046/j.1365-3040.2001.00778.x

ALHASAWI, A.; CASTONGUAY, Z.; APPANNA, N.D.; AUGER, C.; APPANNA, V.D. Glycine metabolism and anti-oxidative defense mechanisms in Pseudomonas fluorescens. Microbiological Research, v.171, p.26-31, 2015. https://doi.org/10.1016/j.micres.2014.12.001

ANDRADE, C.A.; SOUZA, K.R.D.; OLIVEIRA SANTOS, M.; SILVA, D.M.; ALVES, J.D. Hydrogen peroxide promotes the tolerance of soybeans to waterlogging. Scientia Horticulturae, v.232, p.40-45, 2018. https://doi.org/10.1016/j.scienta.2017.12.048

AZEVEDO, R.A.; ALAS, R.M.; SMITH, R.M.; LEA, P.J. Response of antioxidant enzymes to transfer from elevated carbon dioxide to air and ozone fumigation, in the leaves and roots of wild-type and a catalase-deficient mutant of barley. Physiologia Plantarum, v.104, p.280-292, 1998.

BARROS, A.S.R. Teste de frio. In: KRZYZANOWSKI, F.C.; VIEIRA, R.D.; FRANÇA-NETO, J.B. (Ed.) Vigor de sementes: conceitos e testes. ABRATES, 1999. p.5.1-5.12.

BRAND, S.C.; ANTONELLO, L.M.; MUNIZ, M.F.B.; BLUME, E.; SANTOS, V.J.; REINIGER, L.R.S. Qualidade sanitária e fisiológica de sementes de soja submetidas a tratamento com bioprotetor e fungicida. Revista Brasileira de Sementes, v.31, n.4, p.87-94, 2009. https://doi.org/10.1590/S0101-31222009000400010

BRASIL. Ministério da Agricultura, Pecuária e Abastecimento. Regras para análise de sementes. Ministério da Agricultura, Pecuária e Abastecimento. Secretaria de Defesa Agropecuária. Brasília, DF: MAPA/ACS, 2009. 399p. https://www.gov.br/agricultura/pt-br/ assuntos/insumos-agropecuarios/arquivos-publicacoes-insumos/2946_regras_analise_sementes.pdf

BRZEZINSKI, C.R.; ABATI, J.; HENNING, F.A.; HENNING, A.A.; FRANÇA-NETO, J.B.; KRZYZANOWSKI, F.C.; ZUCARELI, C. Spray volumes in the industrial treatment on the physiological quality of soybean seeds with different levels of vigor. Journal of Seed Science, v.39, n.2, p.174-181, 2017. https://doi.org/10.1590/2317-1545v39n2175179

CARVALHO, E.R.; ROCHA, D.K.; ANDRADE, D.B.D.; PIRES, R.M.D.O.; PENIDO, A.C.; REIS, L.V. Phytotoxicity in soybean seeds treated with phytosanitary products at different application times. Journal of Seed Science, v.42, e202042036, 2020. https://www.scielo. br/scielo.php?pid=S2317-15372020000100131\&script=sci_arttext

CHAPARZADEH, N.; AMICO, M.; NEJAD, R.K.; IZZO, R.; IZZO, F.N. Antioxidative responses of Calendula officinalis under salinity conditions. Plant Physiology and Biochemistry, v.42, n.9, p.695-701, 2004. https://doi.org/10.1016/j.plaphy.2004.07.001

EBONE, L.A.; CAVERZAN, A.; TAGLIARI, A.; CHIOMENTO, J.L.T.; SILVEIRA, D.C.; CHAVARRIA, G. Soybean seed vigor: uniformity and growth as key factors to improve yield. Agronomy, v.10, n.4, p.545, 2020. https://doi.org/10.3390/agronomy10040545

FEHR, W.R.; CAVINESS, C.E. Stages of soybean development (p.80). Rep: lowa State University. Cooperative Extension Service Spec, 1977.

FINCH-SAVAGE, W.E.; BASSEL, G.W. Seed vigor and crop establishment: extending performance beyond adaptation. Journal of Experimental Botany, v.67, n.3, p.567-591, 2016. https://doi.org/10.1093/jxb/erv490

FRANÇA-NETO, J.B.; KRZYZANOWSKI, F.C.; HENNING, A.A.; PÁDUA, G.P.; LORINI, I.; HENNING, F.A. Tecnologia da produção de semente de soja de alta qualidade. Documentos / Embrapa Soja, no 380. Londrina: Embrapa Soja, 2016.

GAO, S.; YAN, R.; CAO, M.; YANG, W.; WANG, S.; CHEN, F. Effects of copper on growth, antioxidant enzymes and phenylalanine ammonia-lyase activities in Jatropha curcas L. seedling. Plant, Soil and Environment, v.54, n.3, p.117-22, 2008. https://doi. org/10.17221/410-PSE

HEATH, R.L.; PACKER, L. Photoperoxidation in isolated chloroplasts. I. Kinetics and stoichiometry of fatty acid peroxidation. Archives of Biochemistry and Biophysics, v.125, n.1, p.189-198, 1968. https://doi.org/10.1016/0003-9861(68)90654-1

HOFFMASTER, A.L.; FUJIMURA, K.; MCDONALD, M.B.; BENNET, M.A. An automated system for vigor testing three-day-old soybean seedlings. Seed Science and Technology, v.31, n.3, p.701-713, 2003. http://www.ingentaconnect.com/content/ista/ sst/2003/00000031/00000003/art00019 
KRAUS, T.E.; MCKERSIE, B.D.; FLETCHER, R.A. Paclobutrazol-induced tolerance of wheat leaves to paraquat may involve increased antioxidant enzyme activity. Journal of Plant Physiology, v.145, n.4, p.570-576, 1995. https://doi.org/10.1016/S0176-1617(11)81790-6

LAMICHHANE, J.R.; CONSTANTIN, J.; SCHOVING, C.; MAURY, P.; DEBAEKE, P.; AUBERTOT, J.N.; DÜRR, C. Analysis of soybean germination, emergence, and prediction of a possible northward establishment of the crop under climate change. European Journal of Agronomy, v.113, p.125972, 2020. https://doi.org/10.1016/j.eja.2019.125972

MAGUIRE, J.D. Speed of germination-aid selection and evaluation for seedling emergence and vigor. Crop Science, v.2, n.2, p.176177, 1962. https://doi.org/10.2135/cropsci1962.0011183X000200020033x

MARCOS-FILHO, J. Fisiologia de sementes de plantas cultivadas, 2.ed. Londrina: ABRATES, 2015. 659p.

MARCOS-FILHO, J.; KIKUTI, A.L.P.; LIMA, L.B. Métodos para avaliação do vigor de sementes de soja, incluindo análise computadorizada de imagens. Revista Brasileira de Sementes, v.31, n.1, p.102-112, 2009. https://doi.org/10.1590/S0101-31222009000100012

NAKAGAWA, J. Testes de vigor baseados na avaliação de plântulas. In: KRZYZANOWSKI, F.C.; VIEIRA, R.D.; FRANÇA-NETO, J.B. (Ed.). Vigor de sementes: conceitos e testes. Londrina: ABRATES, 1999. p.21-24.

OLIVER, R.P.; HEWITT, H.G. Fungicides in crop protection. Boston: CABI, 2014. 2nd ed. 200p.

SARTORI, F.F.; PIMPINATO, R.F.; TORNISIELO, V.L.; ENGROFF, T.D.; JACCOUD-FILHO, D.S.; MENTEN, J.O.; DORRANCE, A.E.; DOURADONETO, D. Soybean seed treatment: how do fungicides translocate in plants? Pest Management Science, v.76, n.7, p.2355-2359, 2020. https://doi.org/10.1002/ps.5771

SCHUCH, L.O.B.; KOLCHINSKI, E.M.; FINATO, J.A. Qualidade fisiológica da semente e desempenho de plantas isoladas em soja. Revista Brasileira de Sementes, v.31, n.1, p.144-149, 2009. https://doi.org/10.1590/S0101-31222009000100016

SUDISHA, J.; NIRANJANA, S.R.; SUKANYA, S.L.; GIRIJAMBA, R.; LAKSHMI-DEVI, N.; SHETTY, H.S. Relative efficacy of strobilurin formulations in the control of downy mildew of sunflower. Pesticide Biochemistry and Physiology, v.83, n.4, p.461-470, 2010. https://doi.org/10.1007/s10340-010-0316-3

TEHRANI, H.S.; MOOSAVI-MOVAHEDI, A.A. Catalase and its mysteries. Progress in Biophysics and Molecular Biology, v.140, p.5-12, 2018. https://doi.org/10.1016/j.pbiomolbio.2018.03.001

TEIXEIRA, W.F.; FAGAN, E.B.; SOARES, L.H.; UMBURANAS, R.C.; REICHARDT, K.; DOURADO-NETO, D.D. Foliar and seed application of amino acids affects the antioxidant metabolism of the soybean crop. Frontiers in Plant Science, v.8, n.327, p1-14, 2017. https:// doi.org/10.3389/fpls.2017.00327

UMBURANAS, R.C.; DONEGÁ, V.C.; QUEIROZ, V.M.; FONTANA, D.C.; BAMPI, D.; DOURADO-NETO, D.; REICHARDT, K. Root attributes and seedling biomass of old and modern soybean cultivars under water deficit. Emirates Journal of Food and Agriculture, v.31, n.9, p.688-696, 2019. https://doi.org/10.9755/ejfa.2019.v31.i9.1994

WEEMS, J.D.; HAUDENSHIELD, J.S.; BOND, J.P.; HARTMAN, G.L.; AMES, K.A.; BRADLEY, C.A. Effect of fungicide seed treatments on Fusarium virguliforme infection of soybean and development of sudden death syndrome. Canadian Journal of Plant Pathology, v.37, n.4, p.435-447, 2015. https://doi.org/10.1080/07060661.2015.1115781 use, distribution, and reproduction in any medium, provided the original work is properly cited. 